\title{
STUDI EKSPLORASI SARANA PRASARANA PRAKTIK DAN MOTIVASI BELAJAR SISWA SMK
}

\author{
Aap Pandriana ${ }^{1}$, Nana Sumarna ${ }^{2}$, Ridwan A.M. Noor ${ }^{3}$ \\ Universitas Pendidikan Indonesia \\ Jl. Dr. Setiabudhi No. 229 Bandung 40154 \\ aappandriana@yahoo.com
}

\begin{abstract}
ABSTRAK
Penelitian ini bertujuan untuk mengetahui ketersediaan sarana prasarana di bengkel TKR dan mengetahui motivasi belajar siswa pada mata pelajaran produktif. Metode penelitian yang digunakan adalah metode observasi dan penyebaran angket untuk mengetahui tingkatan motivasi pada siswa. Adapun partisipan pada penelitian ini adalah siswa kelas XI TKR, Kepala Paket Keahlian TKR, serta Kepala Sekolah SMK Negeri 1 Soreang. Hasil dari penelitian ini adalah ketersedian sarana dan prasarana praktik pada kompetensi keahlian TKR di SMK Negeri 1 Soreang masih belum sepenuhnya tercapai sesuai standar yang telah ditetapkan pada Peraturan Menteri Pendidikan Nasional Nomor 40 Tahun 2008 Tentang Standar Sarana dan Prasarana Sekolah Menengah Kejuruan/ Madrasah Aliyah Kejuruan. Hal ini dibuktikan dengan rata-rata persentase ketercapaian sarana 50,44\%, yang artinya tingkat pencapaian sarana di bengkel TKR setengahnya telah sesuai dengan standar. Ketercapaian peralatan kerja pada mata pelajaran produktif kelas XI semester ganjil $59,09 \%$ yang artinya tingkat pencapaian peralatan kerja lebih dari setengahnya telah sesuai dengan jumlah standar. Ketercapaian prasarana yang meliputi luas dan rasio hanya mencapai $25 \%$ yang artinya hanya sebagian kecil prasarana di bengkel TKR yang sesuai dengan standar. Motivasi berdasarkan uraian persentase pencapaian kebutuhan berdasarkan indikator yang telah ditentukan, bahwa rata-rata motivasi belajar siswa kelas XI pada mata pelajaran produktif mencapai 75\%. Artinya lebih dari setengahnya siswa kelas XI memiliki motivasi dalam belajar khususnya pada mata pelajaran produktif.
\end{abstract}

Kata kunci: motivasi belajar, sarana dan prasarana praktik, kendaraan ringan.

\section{PENDAHULUAN}

Pengembangan kompetensi siswa dibutuhkan sarana dan prasarana praktik yang cukup untuk menunjang siswa SMK dalam pembelajaran praktikum. Proses pembelajaran melalui praktikum di bengkel merupakan perwujudan dari suatu teori ke dalam bentuk nyata. Kegiatan praktik juga akan memberikan pengalaman yang tidak diperoleh dalam teori. Kegiatan praktik merupakan suatu cara yang ditempuh untuk memberdayakan bengkel praktik di SMK, agar benar-benar dapat dimanfaatkan siswa sebagai sarana pembelajaran praktik. Sarana prasarana praktik merupakan salah satu faktor penentuan terhadap prestasi belajar siswa. Maka sarana prasarana praktik harus sesuai dengan kebutuhan dalam mencapai suatu kompetensi tertentu, Seperti yang tercantum pada UUSPN No. 20 Tahun 2003 Bab 12 Pasal 45 tentang sarana dan prasarana bahwa: setiap satuan pendidikan formal dan nonformal menyediakan sarana dan prasarana yang memenuhi keperluan pendidikan sesuai dengan pertumbuhan dan perkembangan potensi fisik, kecerdasan intelektual, sosial, emosional, dan kejiwaan peserta didik.

\footnotetext{
${ }^{1}$ Mahasiswa Departemen Pendidikan Teknik Mesin FPTK, UPI

2 Dosen Departemen Pendidikan Teknik Mesin FPTK, UPI

${ }^{3}$ Dosen Departemen Pendidikan Teknik Mesin FPTK, UPI
} 
SMK Negeri 1 Soreang adalah sekolah menengah kejuruan Negeri dengan berbagai jurusan, diantaranya Teknik Komputer dan Informasi, Teknik Elektronika Industri, Teknik Mesin Produksi, Akomodasi Perhotelan, dan Teknik Kendaraan Ringan. Penelitian ini dikhususkan pada jurusan Teknik Kendaraan Ringan. Secara visual sarana dan prasarana Teknik Kendaraan Ringan di SMK Negeri 1 Soreang masih belum memadai. Kelengkapan sarana dan prasarana merupakan komponen penting yang dapat mempengaruhi proses pembelajaran. Sarana adalah segala sesuatu yang mendukung secara langsung terhadap kelancaran proses pembelajaran, misalnya media pembelajaran, alat-alat pembelajaran, perlengkapan sekolah, dan lain sebagainya (Sanjaya, 2008). Sedangkan prasarana adalah segala sesuatu yang secara tidak langsung dapat mendukung keberhasilan proses pembelajaran, misalnya jalan menuju sekolah, penerangan sekolah, kamar kecil, dan lain sebagainya.

Kurangnya kelengkapan sarana dan prasarana ini mengakibatkan siswa kurang menguasai kompetensi tertentu dan berpengaruh pada prestasi belajar siswa. Sarana dan prasarana praktik di SMK Negeri 1 Soreang masih belum memadai dalam menunjang pencapaian kompetensi. Fasilitas yang tersedia masih sangat terbatas dan tidak sesuai dengan yang tercantum pada UUSPN No. 20 Tahun 2003 Bab 12 Pasal 45 tentang sarana dan prasarana. Secara lebih spesifik standar sarana dan prasarana pendidikan SMK tertuang dalam Peraturan Menteri Pendidikan Nasional Nomor 40 Tahun 2008 tentang Standar Sarana dan Prasarana untuk Sekolah Menengah Kejuruan/Madrasah Aliyah Kejuruan.

Area kerja mesin otomotif yaitu $6 \mathrm{~m}^{2} /$ peserta didik, kapasitas untuk 16 peserta didik, luas minimum adalah $96 \mathrm{~m}^{2}$ dan lebar minimum adalah $8 \mathrm{~m}$. Area kerja kelistrikan yaitu 6 $\mathrm{m}^{2} /$ peserta didik untuk apasitas untuk 8 peserta didik, luas minimum adalah $48 \mathrm{~m}^{2}$ dan lebar minimum adalah $6 \mathrm{~m}$. Area kerja chasis dan pemindah tenaga yaitu $8 \mathrm{~m}^{2} /$ peserta didik untuk kapasitas untuk 8 peserta didik, luas minimum adalah $64 \mathrm{~m}^{2}$ dan lebar minimum adalah $8 \mathrm{~m}$. Ruang penyimpanan dan instruktur yaitu $4 \mathrm{~m}^{2} /$ instruktur dengan luas minimum adalah $48 \mathrm{~m}^{2}$ dan lebar minimum adalah $6 \mathrm{~m}$.

Kondisi ini mengakibatan kurangnya motivasi siswa dalam belajar. Hal ini dibuktikan dengan banyaknya siswa yang tidak hadir untuk melakukan pembelajaran praktikum. Sarana prasarana merupakan salah satu faktor yang mempengaruhi belajar. Alat pelajaran erat hubungannya dengan cara belajar siswa, karena alat pelajaran yang dipakai oleh gurupada waktu mengajar dipakai pula oleh siswa untuk menerima bahan yang diajarkan. Dengan jumlah siswa yang banyak serta variasi karakteristik mereka masing- 
masing menuntut keadaan gedung harus memadai agar siswa dapat belajar dengan nyaman (Slameto, 2013).

Motivasi merupakan salah satu aspek psikis yang memiliki pengaruh terhadap pencapaian prestasi belajar (Sardiman, 2011). Istilah motif dalam psikologi sering dibedakan dengan istilah motivasi. Kata "motif" diartikan sebagai daya upaya yang mendorong seseorang untuk melakukan sesuatu. Tingkah laku manusia dibangkitkan dan diarahkan oleh kebutuhan-kebutuhan tertentu. Kebutuhan-kebutuhan ini (yang memotivasi tingkah laku manusia) dibagi oleh Maslow ke dalam 7 kategori yaitu: fisiologis, rasa aman, rasa cinta, penghargaan, aktualisasi diri, mengethui dan mengerti, dan kebutuhan estetik.

\section{METODE PENELITIAN}

Metode penelitian yang digunakan adalah metode deskriptif dengan melakukan observasi dan penyebaran angket untuk mengetahui tingkatan motivasi pada siswa. Metode ini dilakukan dengan menempuh langkah-langkah pengumpulan, klasifikasi, dan analisis data pengolahan data, membuat kesimpulan, dan laporan dengan tujuan utama untuk membuat gambaran tentang sesuatu keadaan secara objektif dalam suatu deskripsi situasi”. Itulah sebabnya disebut dengan metode deskriptif.

Alat pengumpulan data mengenai sarana dan prasarana menggunakan lembar obsevasi dengan bentuk checklist. Alat pengumpul data mengenai motivasi menggunakan lembar angket dengan skala likert. Secara deskriptif disertai dengan kata-kata yang memperkuat temuan yang ada. Data yang diperoleh dari penelitian ini seperti jumlah ketersediaan sarana dan prasarana praktik, observasi, dokumentasi

\section{HASIL PENELITIAN}

Jumlah Sekolah Menengah Kejuruan di Kabupaten Bandung masih kurang sebanding dengan jumlah Sekolah Menengah Atas. Selanjutnya perbandingan jumlah siswa dengan luas ruang praktik di SMK Negeri 1 Soreang dapat dilihat pada diagram perbandingan. Perbandingan antara ruang teori dan ruang praktik yang ada di SMK Negeri 1 Soreang, yaitu ruang teori $63 \%$ dan ruang praktik $37 \%$. Perbandingan jumlah siswa dengan luas ruang teori di SMK Negeri 1 Soreang dapat dilihat pada diagram perbandingan. Ruang yang digunakan untuk ruang praktik sebagai berikut: ruang teknik kendaraan ringan $65 \%$, teknik komputer $15 \%$, eletronika industri $16 \%$ dan mesin produksi tidak memiliki ruangan khusus. Ruang yang digunakan untuk ruang praktik sebagai berikut: ruang teknik 
kendaraan ringan $23 \%$, teknik komputer $17 \%$, eletronika industri $23 \%$ dan mesin produksi $23 \%$.

\section{PEMBAHASAN}

Aspek-aspek yang akan dibahas pada pembahasan hasil penelitian ini adalah kondisi sarana dan prasarana workshop otomotif yang mencakup luas dan rasio area kerja mesin otomotif, area kerja kelistrikan otomotif, area kerja chasis dan pemindah tenaga, area ruang penyimpanan dan instruktur, kondisi peralatan kerja pada mata pelajaran produktif kelas XI semester ganjil, dan kondisi motivasi belajar siswa kelas XI pada mata pelajaran produktif semester ganjil.

Persentase tingkat pencapaian standar sarana pada area kerja mesin otomotif hanya mencapai $28,57 \%$. artinya secara kuantitas tingkat pencapaian standar sarana pada area kerja mesin otomotif sebagian kecil telah sesuai dengan standar yang ditetapkan. Persentase tingkat pencapaian standar sarana pada area kerja kelistrikan otomotif hanya mencapai $42,85 \%$. Artinya secara kuantitas tingkat pencapaian standar sarana pada area kerja Kelistrikan otomotif kurang dari setengahnya telah sesuai dengan standar yang ditetapkan. Persentase tingkat pencapaian standar sarana pada area kerja chasis dan pemindah tenaga hanya mencapai $42,85 \%$. Artinya secara kuantitas tingkat pencapaian standar sarana pada area kerja chasis dan pemindah tenaga kurang dari setengahnya telah sesuai dengan standar yang ditetapkan.

Persentase tingkat pencapaian standar sarana pada area ruang penyimpanan dan instruktur mencapai $87,5 \%$. Artinya secara kuantitas tingkat pencapaian standar sarana pada area ruang penyimpanan dan instruktur sebagian besar telah sesuai dengan standar yang ditetapkan. Persentase tingkat pencapaian ketersediaan peralatan kerja pada mata pelajaran produktif kelas XI semester ganjil hanya mencapai 59\%. Artinya secara kuantitas tingkat pencapaian ketersediaan peralatan kerja lebih dari setengahnya telah sesuai dengan jumlah standar.

Persentase tingkat pencapaian standar prasarana yang meliputi luas dan rasio pada area kerja mesin otomotif, area kerja kelistrikan otomotif, area kerja chasis dan pemindah tenaga, serta ruang penimpanan dan instruktur hanya mencapai $25 \%$. Artinya secara kuantitas tingkat pencapaian standar prasarana pada workshop otomotif sebagian kecil telah sesuai dengan standar yang ditetapkan. 
Tingkat pencapaian kebutuhan fisiologis dalam hal mempertahankan hidup mencapai 63\%. Artinya secara kuantitas tingkat pencapaian kebutuhan fisiologis lebih dari setengahnya telah tercapai. Tingkat pencapaian rasa aman dalam hal kepastian keadaan dan lingkungan, mencapai 75\% Artinya secara kuantitas tingkat pencapaian kebutuhan rasa aman lebih dari setengahnya telah tercapai. Tingkat pencapaian rasa cinta dilihat dari pertalian atau hubungan dengan orang lain, mencapai $82 \%$. Artinya secara kuantitas tingkat pencapaian kebutuhan rasa cinta sebagian besar telah tercapai. Tingkat pencapaian penghargaan terhadap diri atau rasa berguna bagi orang lain, mencapai $69 \%$. Artinya secara kuantitas tingkat pencapaian penghargaan terhadap diri lebih dari setengahnya telah tercapai. Tingkat pencapaian aktualisasi diri atau pengembangan diri, mencapai $74 \%$. Artinya secara kuantitas tingkat pencapaian kebutuhan aktualisasi diri lebih dari setengahnya telah tercapai. Tingkat pencapaian memuaskan rasa ingin tahu, mencapai $81 \%$. Artinya secara kuantitas tingkat pencapaian memuaskan rasa ingin tahu sebagian besar telah tercapai. Tingkat pencapaian kebutuhan estetik atau keteraturan, mencapai 82\%. Artinya secara kuantitas tingkat pencapaian kebutuhan estetik atau keteraturan sebagian besar telah tercapai. Pencapaian kebutuhan berdasarkan indikator yang telah ditentukan, bahwa rata-rata motivasi belajar siswa kelas XI pada mata pelajaran produktif mencapai $75 \%$.

\section{KESIMPULAN}

Penelitian ini dapat disimpulkan, bahwa sarana dan prasarana praktik pada kompetensi keahlian Teknik Kendaraan Ringan di SMK Negeri 1 Soreang masih belum sepenuhnya tercapai sesuai standar yang telah ditetapkan. Hal ini dibuktikan dengan ratarata persentase ketercapaian sarana yaitu 50,4\%. Ketercapaian peralatan kerja pada mata pelajaran produktif kelas XI semester ganjil hanya mencapai 59,1\%. Ketercapaian prasarana yang meliputi luas dan rasio hanya mencapai 25\%. Rata-rata motivasi belajar siswa kelas XI pada mata pelajaran produktif mencapai $75 \%$.

\section{REFERENSI}

Sanjaya, W. (2008). Kurikulum dan Pembelajaran. Jakarta: Kencana.

Sardiman. (2005). Interaksi dan Motivasi Belajar Mengajar. Jakarta: Rajawali Pers.

Slameto. (2013). Belajar dan Faktor-faktor yang Mempengaruhinya. Jakarta: Rineka Cipta. 